\title{
Desensitization of the actin polymerization response in human neutrophils at low cell density
}

\author{
Michael A. Model* and Geneva M. Omann' \\ Departments of 'Surgery and 'Biological Chemistry and *Biophysics Research Division, University of Michigan \\ and 'VA Medical Center, Ann Arbor, Michigan
}

\begin{abstract}
Many chemoattractant-activated responses in neutrophils show transient kinetics, suggesting that rapid desensitization occurs during the time course of the response. We found that desensitization of the actin polymerization response to $\boldsymbol{N}$-formyl peptides is, in a large part, due to inhibition by adenosine released from cells to the medium and depletion or a chemical inactivation of the agonist. To reduce the influence of these factors, we stimulated neutrophils in a very diluted suspension, sometimes with continuous replacement of the medium. The actin polymerization response to a high agonist concentration was greatly enhanced and prolonged under these conditions, often without any tendency to subside within $10 \mathrm{~min}$ at $25^{\circ} \mathrm{C}$. It has previously been shown that the $\boldsymbol{N}$-formyl peptide receptor converts from a rapidly dissociating to a slowly dissociating and presumably inactive form during activation. Under the conditions of low cell concentration, the conversion to a slowly dissociating receptor still occurred. Thus the prolonged response was not due to prolonged presence of rapidly dissociating receptors. We conclude either that a low number of rapidly dissociating receptors, which we failed to see, is sufficient to maintain actin polymerization or that slowly dissociating receptors can support the actin response. In contrast to responses stimulated by high agonist concentrations, the responses to low concentrations of the agonists were transient. The results of other authors indicate that low concentrations of $\boldsymbol{N}$-formyl peptides do not desensitize the receptors. Other mechanisms, which are specific for the actin polymerization response, must be involved in response termination to low concentrations of $\boldsymbol{N}$-formyl peptides. Activation at low cell density will be a useful approach for studying other processes ( $\mathrm{Ca}^{2+}$ elevation, oxidant production, etc.) and chemoattractants (leukotriene $B_{4}$, interleukin 8, etc.) for which an understanding of the kinetics due to desensitization of the components of the receptor-mediated activation pathway is desired.J. Leukoc. Biol. 58: 331-341; 1995.
\end{abstract}

Key Words: kinetics · f-Met-Leu-Phe $\cdot$ chemoattractants

\section{INTRODUCTION}

$N$-formyl peptides are among the best-characterized neutrophil chemoattractants. Binding of an $N$-formyl peptide to its receptor activates a cascade of responses in the neutrophil: opening of ion channels, protein phosphorylation, generation of $\mathrm{H}_{2} \mathrm{O}_{2}$ and $\mathrm{O}_{2}{ }^{-}$, and actin polymerization [1]. Although biochemical pathways leading to the chemoattractant-induced responses remain in many in- stances unclear, they all require activation of $\mathbf{G}$ proteins $\left(G_{i}\right.$ type). Desensitization is another feature common to many responses: exposure of neutrophils to a chemoattractant may result in loss of sensitivity of the response to the stimulus [2-6].

Several processes are believed to contribute to desensitization. Internalization of ligand-receptor complexes may significantly reduce the number of available receptors on the plasma membrane [7]. In addition, the remaining receptors become less efficient in stimulating GTPase activity $[8,9]$. The latter may be related to an increased receptor association with cytoskeleton as a result of chemotactic stimulation [10-12] and removal of G proteins into separate membrane microdomains [13]. Phosphorylation may also play a role in desensitization [14-17]. The fact that different responses do not desensitize simultaneously $[18,19]$, as well as the observation of direct inactivation of distant steps in signal transduction $[20,21]$, points at the possibility that specific reactions past activation of the $G$ proteins may become desensitized. The actin polymerization response, which is a subject of the present study, was found to be enhanced in the absence of calcium; that led to the hypothesis that intracellular calcium, which is released into the cytosol upon chemotactic stimulation in a calcium-containing buffer, serves as an additional turnoff signal $[22,23]$.

Desensitization to chemical stimuli is commonly demonstrated in two types of experiments: a single stimulation protocol and a double stimulation protocol. In the first, the response is observed continuously after a single addition of an agonist, and desensitization is judged by a decrease in the response magnitude that may occur after some time of stimulation. In experiments of the second type, the cells are activated with two additions of agonist, and a reduction in ability of the cells to respond to the second addition is interpreted as desensitization. In this protocol the stimulus from the first addition is usually

Abbreviations: BSA, bovine serum albumin; BSA-FITC, fluorescein isothiocyanate-labeled bovine serum albumin; $E D_{50}$, effective dose that gives $50 \%$ of maximal response; fMLP, $N$-formyl-Met-Leu-Phe; FNLPNTLFITC, $N$-formyl-Nle-Leu-Phe-Nle-Tyr-Lys-fluorescein; $G$ proteins, guanine nucleotide binding proteins; HDS, high-density cell suspension $\left(5 \times 10^{6}\right.$ cells $/ \mathrm{ml}$ ); $\boldsymbol{K}_{\mathrm{d}}$, dissociation constant; $\boldsymbol{k}_{\mathrm{on}}$, association rate constant; LDS, low-density cell suspension $\left(2-5 \times 10^{4}\right.$ cells $\left./ \mathrm{ml}\right) ; \mathrm{MGB}$, modified Gey's buffer $\left(147 \mathrm{mM} \mathrm{NaCl}, 5 \mathrm{mM} \mathrm{KCl}, 0.22 \mathrm{mM} \mathrm{KH}_{2} \mathrm{PO}_{4}, 1.1 \mathrm{mM} \mathrm{Na}_{2} \mathrm{HPO}_{4}\right.$, $0.3 \mathrm{mM} \mathrm{MgSO}_{4}, 1 \mathrm{mM} \mathrm{MgCl}, 5.5 \mathrm{mM}$ dextrose, and $10 \mathrm{mM} \mathrm{HEPES}, \mathrm{pH}$ 7.4); NBD phallacidin, $N$-(7-nitrobenz-2-oxa-1,3-diazol-4-yl)phallacidin; SOD, superoxide dismutase.

Reprint requests: Geneva M. Omann, Research Service 151, VA Medical Center, 2215 Fuller Road, Ann Arbor, MI 48105.

Received March 25, 1995; accepted May 29, 1995. 
washed away before the second stimulation. Sometimes, the washing step is omitted; in this case, the second stimulation should be done with a much higher concentration of the stimulus than the first one. Both approaches have advantages and disadvantages. The double stimulation with the wash step permits a direct comparison of cell responsiveness before and after exposure to a stimulus, however, it tests only for a long-lasting desensitization. Continuous observation of the response may be more sensitive but it is often based on the reaction to a nonphysiological, abrupt pulse of agonist concentration. It is also particularly sensitive to a number of additional factors, such as secretion of biologically active compounds into the medium in response to stimulation and degradation of the agonist. Neutrophils, for instance, can produce and secrete interleukins [24], prostaglandins [25], adenosine [26], etc. Their influence on the kinetics of the response to an exogenous stimulus may be complex: some of them (interleukin-8, platelet-activating factor, leukotriene $B_{4}$ ) are chemoattractants in their own right and, in fact, their release accounts for a number of observed phenomena [27]; others (prostaglandins, adenosine) can oppose activation via $\mathrm{G}_{\mathrm{s}}$-adenylyl cyclase mechanisms [28]; free radicals and proteases can destroy the stimulus $[29,30]$. These factors may represent physiological mechanisms of the response control and make an important area of study. However, if one is interested in basic signaling reactions necessary for a response to occur, then having a medium with a simple and well-known composition makes interpretation of the results easier.

Desensitization of the actin polymerization response in neutrophils is readily demonstrated by using a continuous stimulation approach but is less apparent with repetitive stimulation [31]. In the present work we characterize desensitization as observed with the continuous stimulation method and evaluate the cumulative contribution of cellderived factors in the medium to termination of the actin response. We describe the steps we took to reduce the influence of these factors and obtain the response kinetics under conditions of a constant concentration of a chemoattractant and a buffer minimally contaminated with cellular products. We then use these conditions to study the characteristics and mechanisms of desensitization of the $N$-formyl peptide-induced actin polymerization response.

\section{MATERIALS AND METHODS}

\section{Chemicals}

N-Formyl-Met-Leu-Phe (fMLP), bovine serum albumin (BSA), BSA-fluorescein isothiocyanate (FITC), FITC phalloidin, lysophosphatidylcholine from egg yolk, catalase from bovine liver $(50 \mathrm{U} / \mu \mathrm{g})$, SOD from bovine erythrocytes $(3.4 \mathrm{U} / \mu \mathrm{g})$, adenosine deaminase from calf intestinal mucosa $(0.19 \mathrm{U} / \mu \mathrm{g})$, and antifluorescein antibody were purchased from Sigma Chemical Co. (St. Louis, MO); $N$-formyl-Nle-Leu-Phe-Nle-Tyr-Lysfluorescein (FNLPNTL-FITC) and nitrobenzoxadiazol (NBD) phat lacidin were obtained from Molecular Probes (Eugene, OR); $\left[{ }^{3} \mathrm{H}\right] \mathrm{fMLP}$ (56.4 Ci/mmol) was obtained from New England Nuclear (Boston, MA). Statistical analysis was done with the GraphPad statistical program.

\section{Isolation and stimulation of neutrophils}

Neutrophils were isolated from the venous blood of healthy volunteers using a counterflow centrifugation method [32]. The first purification step was a crude cell separation on gelatin. That was followed by counterflow centrifugation, yielding a 95-99\% pure neutrophil preparation. The cells were finally resuspended in modified Gey's buffer (MGB) without calcium and kept refrigerated until used.
Stimulation with chemotactic peptides was carried out in MGB sup plemented with $1 \mathrm{mg} / \mathrm{ml} \mathrm{BSA}$ to prevent nonspecific adsorption of the peptides to plastic. The cell suspension was placed in a polystyrene spectrophotometric cuvette and kept there with stirring for about 10 min before addition of a stimulus. Three different conditions for cell stimulation were used: (1) bolus addition of the stimulus into a high-density cell suspension (HDS, $5 \times 10^{6}$ cells $/ \mathrm{ml}$ ); (2) bolus addition into a low-density suspension (LDS, $2-5 \times 10^{4}$ cells $/ \mathrm{ml}$ ); (3) bolus addition of the peptide into HDS, followed by continuous perfusion with the buffer containing the agonist at the same concentration as in the suspension. In the perfusion experiments the medium was added with an infusion pump (Harvard Apparatus, South Natick, MA) to a stirred cuvette containing cells at an initial concentration of $5 \times 10^{6}$ cells $/ \mathrm{ml}$. The constant level of liquid in the cuvette was maintained by removing extra buffer together with cells through tubing connected to a vacuum. Unless otherwise indicated, the medium was exchanged at a rate of 1 volume $/ \mathrm{min}$; the maximal duration of the experiment, when the remaining cells could still be analyzed, was about $8 \mathrm{~min}$. Perfusion with buffer without a chemoattractant did not change the F-actin levels by more than $2-3 \%$ of the initial value.

Perfusion experiments were done at room temperature $\left(22-25^{\circ} \mathrm{C}\right)$. When perfusion results were compared to a bolus injection, the bolus injection experiments were also done at room temperature; otherwise the temperature in these experiments was kept at $25^{\circ} \mathrm{C}$ or $15^{\circ} \mathrm{C}$, as indicated.

\section{Analysis of the actin polymerization response}

At specified time points during the activation of neutrophils, aliquots of the cell suspension were diluted into a 10 - or 15 -fold excess of $3.7 \%$ formaldehyde buffered with MGB and fixed there overnight. The cells were then concentrated, if needed, by centrifugation at $2000 \mathrm{~g}$ and resuspended in a volume of $100 \mu \mathrm{l}$. We found that, after the cellis had been in formaldehyde overnight, NBD phallacidin staining was the same regardless of cell concentration and whether or not cells were centrifuged (Fig. 1). Staining and analysis were based on the known proce dure using NBD phallacidin to quantify F-actin [33]. One hundred microliters of $3.7 \%$ formaldehyde with $0.02 \%$ lysophosphatidylcholine and either $0.33 \mu \mathrm{M}$ NBD phallacidin or $0.1 \mu \mathrm{M}$ FITC phalloidin were added to the cells (results obtained with these two reagents were qualitatively similar). After at least $1 \mathrm{~h}$ of staining, the cells were analyzed with a flow cytometer (FACScan, Becton Dickinson, Braintree, MA). A wash or dilution step prior to the measurement was omitted because it resulted in dissociation of some dye from the cells within the time required to collect data. Previous authors did not observe dissociation of NBD phallacidin from fixed cells [33], which could have been due to a shorter fixation time used in their experiments. Fluorescence of NBD phallacidin present in solution was insignificant and did not interfere with the measurements. The protocol yielded a staining that did not depend on the cell concentration in a wide range (Fig. 1). Sometimes, in the low cell density experiments or at the end of the perfusion experiments, only several hundred cells could be analyzed with the flow cytometer. The statistical analysis [34] showed, however, that the mean channel number of the fluorescence distribution could be determined with $99 \%$ confidence within \pm 1-2 channels.' The F-actin levels are given as the percent change above the resting level, that is,

$$
\left[\left(F-F_{0}\right) / F_{0}\right] \times 100 \%
$$

where $F_{0}$ is the fluorescence of resting cells and $F$ is the fluorescence of stimulated cells.

\section{Ligand quantitation in the supernatant}

To determine whether the free ligand concentration decreased during neutrophil activation, two different chemotactic peptides, $\left[{ }^{3} \mathrm{H}\right] \mathrm{HMLP}$ and FNLPNTL-FITC, were quantified in the supernatant. At designated times after addition of the ligand, the external medium was quickly separated from cells by centrifugation and the supernatant was kept on ice until assayed. Samples $(10 \mu \mathrm{l})$ of the supernatant were fractionated by thin-layer chromatography on SG 60 silica gel plates (Merck, Darmstadt, Germany) with a 0.25-mm silica layer using chloroform, methanol, and acetic acid (3:1:0.1) as a solvent [35]. Stripes of silica were scraped off the plate and the peptides were solubilized with $1 \mathrm{ml}$ of $50 \%$

\footnotetext{
'For example, if the number of analyzed cells is $N=300$ and SD $=20$, then the $99 \%$ confidence interval for the mean is $\pm \mathrm{SD} / 2.58 \sqrt{N}= \pm 0.45$.
} 


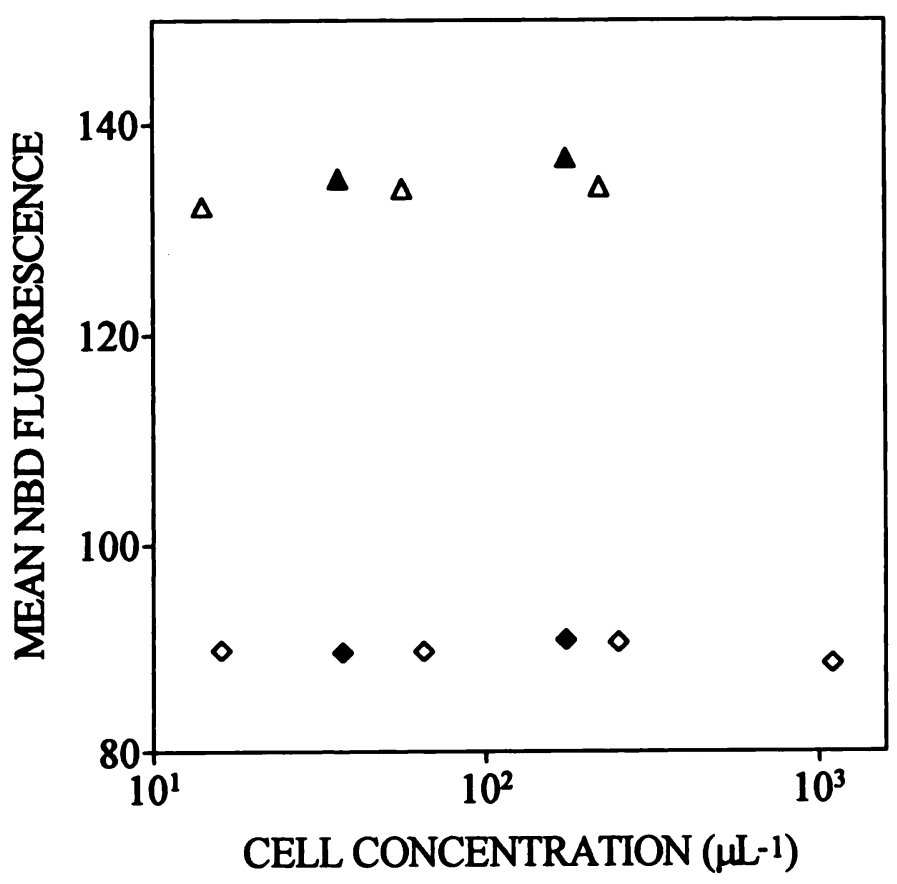

Fig. 1. Lack of effect of cell concentration and centrifugation on staining of neutrophils with NBD phallacidin. Cells in HDS were fixed by a 15-fold dilution into $3.7 \%$ formaldehyde prior to (rhombuses) or $1 \mathrm{~min}$ after (triangles) activation by $0.5 \mu \mathrm{M}$ fMLP. After fixing overnight, some samples were centrifuged at $16,000 \mathrm{~g}$ (open symbols). Samples with different cell concentrations were prepared by further dilution with formaldehyde. Permeabilization, staining with NBD phallacidin, and determination of cell-bound fluorescence were done as described in Materials and Methods. The final cell concentrations were determined with the FACScan and are plotted along the horizontal axis

methanol prior to quantitation. $\left[{ }^{3} \mathrm{H}\right] \mathrm{fML}$. was quantified by radioactivity and FNLPNTL-FITC was quantified by fluorescence. For fluorescence measurements the silica was removed by centrifugation and the water-methanol extract was neutralized with 0.125 volume of $1 \mathrm{M} \mathrm{Na}$ $\mathrm{HCO}_{3}$. Fluorescence of the solution was recorded with an SLM 8000C spectrofluorometer (SLM-Aminco, Urbana, IL) using excitation at 490 $\mathrm{nm}$ and emission through a 520-nm bandpass filter (Corion, Holliston, MA). Low concentrations of FNLPNTL-FITC $(0.1 \mathrm{nM}$ or less) were detected directly in the supernatant because these small quantities of the peptide could not be measured after thin-layer chromatography. Because the background fluorescence of the supernatant was relatively high, we used antifluorescein antibody (final dilution 1:3000), which is known to quench the fluorescence of the free peptide [36]. The decrease in the fluorescence intensity caused by addition of the antibody was used to quantify FNLPNTL-FITC in the supernatant.

Quantitation of FNLPNTL-FITC by its fluorescence had to be given some justification. If oxygen radicals produced by activated neutrophils caused bleaching of fluorescein, the fluorescence would probably be attenuated without a significant change in the biological activity of the peptide. To check for bleaching, we stimulated neutrophils with saturating concentrations of $\mathrm{fMLP}(0.5-1 \mu \mathrm{M})$ in the buffer containing 0.2 $\mathrm{mg} / \mathrm{ml} \mathrm{BSA-FITC}$ and $0.8 \mathrm{mg} / \mathrm{ml} \mathrm{BSA}$, which brought the total BSA concentration to the same level as in the rest of experiments. After 10 min of stimulation, the supernatant was collected and the BSA-FITC fluorescence was measured as described above. These experiments were done at $25^{\circ} \mathrm{C}$ with HDS, LDS, and no cells for control. Each data point represents the average of two to four measurements. Normalizing the control fluorescence to $100 \%$, we obtained for HDS the values $108 \%$, 93\%, and $96 \%$ in three experiments and for LDS $106 \%$ and $96 \%$ in two experiments. Thus, bleaching did not occur to any significant extent under any of the conditions we used, and fluorescence could be used as a reliable measure of FNLPNTL-FITC

\section{Measurement of FNLPNTL-FITC dissociation}

It has previously been shown that during the time course of neutrophil activation receptors convert from a rapidly dissociating form to a slowly dissociating form. Because the experiments demonstrating this interconversion were done in high-density cell suspensions [35], we questioned whether this conversion was altered in LDS. Dissociation kinetics of FNLPNTLFITC were registered using flow cytometry. LDS $\left(5 \times 10^{4}\right.$ cells $/ \mathrm{ml}$ ) was allowed to bind $2.5 \mathrm{nM}$ FNLPNTLFITC at $25^{\circ} \mathrm{C}$ for 0.5 $\mathrm{min}$ or $10 \mathrm{~min}$, and the dissociation was observed after addition of a high concentration of a nonfluorescent peptide ( $0.1 \mathrm{mM}$ fMLP). The time required to add AMLP, mix, and start data collection was about 5 s; thus data for the first 5 s of dissociation were not obtainable. To analyze the data, we set 4-s-wide gates on the time-resolved fluorescence data, and statistics of the fluorescence distribution were obtained for each gate.

\section{RESULTS}

\section{The actin polymerization response is enhanced under} conditions of low cell density and perfusion

Our preliminary results showed that extracellular factors and/or the loss of the agonist may alter the observed kinetics of responses to $N$-formyl peptide in human neutrophils. To minimize these effects, we designed experiments in which stimulation of neutrophils was performed with continuous replacement of the medium or at low cell density. We found that stimulation by continuous perfusion produced a more prolonged response than a single addition of the agonist into HDS (Fig. 2). Activation by a bolus addition of the agonist gave typical rapidly decaying kinetics; however, perfusion with FNLPNTL-FITC or with high concentrations of fMLP often resulted in a stable level of actin. Table 1 shows the effect of experimental conditions on the magnitude of the response. Neutrophils were activated by high and low concentrations of FNLPNTL FITC and fMLP and analyzed $5 \mathrm{~min}$ after addition of the agonist. The responses to perfusion and to a bolus addition of the stimulus into cell suspensions of different densities were compared. The most dramatic effect of the experimental conditions on the response was observed with a low concentration of FNLPNTL-FITC (0.02 nM). After $5 \mathrm{~min}$ of stimulation of cells at $5 \times 10^{6} / \mathrm{ml}$, F-actin levels returned to the baseline. However, at cell concentrations below $1 \times$ $10^{5} / \mathrm{ml}$ and under perfusion conditions, the F-actin was still $20-30 \%$ above the baseline. With high concentrations of either agonist we observed an intermediate effect, and activation by a low concentration of fMLP $(0.5 \mathrm{nM})$ was insensitive to cell concentration or perfusion. When a difference between HDS and LDS was detected, it was statistically highly significant $(P<.001-.004$ by the paired $t$-test); perfusion with FNLPNTL-FITC and AMLP at a high concentration brought about an additional response enhancement over LDS $(P<.004-.03)$.

\section{Response inhibition in HDS correlates with loss of activity in the supernatant}

To investigate the reason for the rapid decay of the response when a stimulus was injected as a bolus into HDS, we first determined the biological activity of the agonist remaining in the supernatant at the end of activation. After incubation of HDS with 0.1 nM FNLPNTLFITC or with $0.5 \mathrm{nM}$ fMLP for $10 \mathrm{~min}$ at room temperature, the sample was centrifuged and the supernatant with remaining free agonist was collected. For the next step, the supernatant was used as a continuous source of the peptide in a perfusion experiment; the initial bolus injection of the agonist into the suspension of fresh cells (see Materials and Methods) was omitted in order to have the supernatant as the only source of the agonist. In the 


\section{0 nM FMLP}

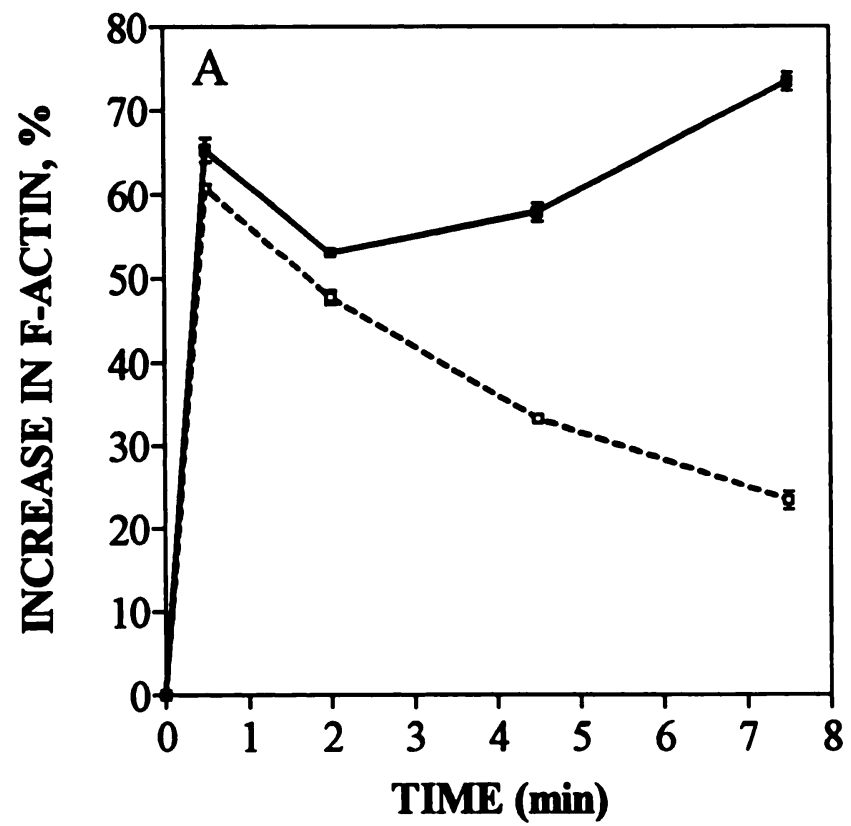

0.02 nM HP-FITC

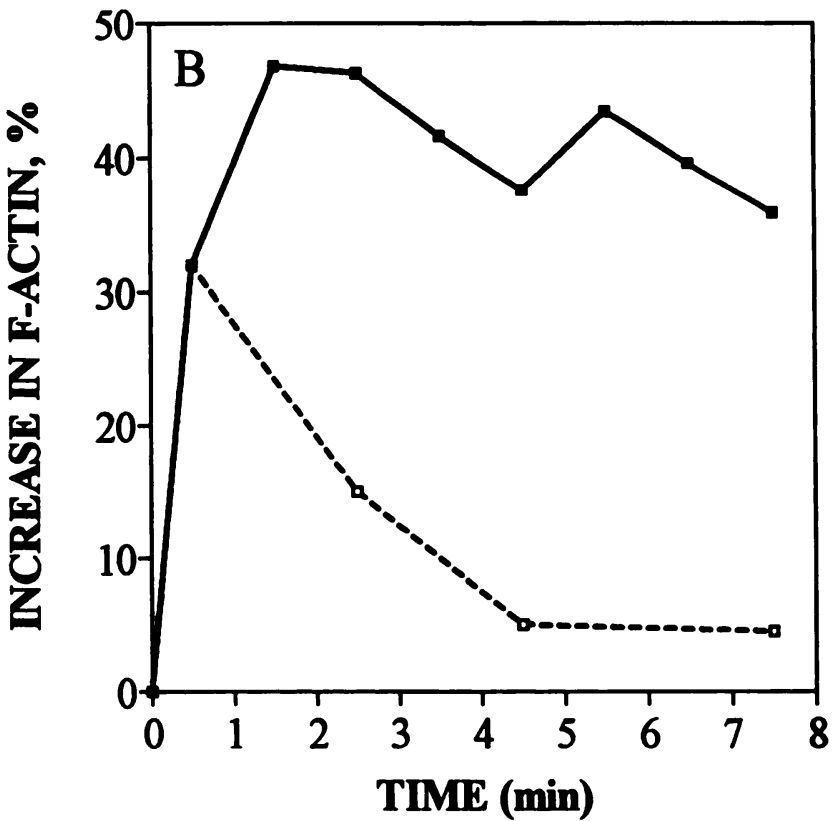

Fig. 2. Actin polymerization response to $100 \mathrm{nM}$ fMLP (A) and $0.02 \mathrm{nM}$ FNLPNTLFITC (B) under conditions of stimulus perfusion (solid lines) and bolus addition into HDS (dashed lines). Activation was performed as described in Materials and Methods.

control experiments we stimulated the cells by perfusing them with the peptides dissolved in MGB with BSA (again without an initial bolus of stimulus) for direct comparison with the test supernatants. The supernatant containing FNLPNTL-FITC showed a greatly diminished ability to stimulate fresh cells (Fig. 3A), suggesting a significant loss of the ligand. With the supernatant containing fMLP, cells were fully stimulated at the beginning of the perfusion but later the response went below the control (Fig. 3B). This result suggested that in this experiment the active agonist remained intact; however, a slowly acting inhibitor of cell activation accumulated in the medium.

The decrease of the N-formyl peptide activity of the supernatant can be due to both ligand loss and accumulation of inhibitors

To determine whether the decrease in the activity of the $\mathrm{N}$-formyl peptide in cell supernatant was due to ligand loss, $\left[{ }^{3} \mathrm{H}\right]$ fMLP or FNLPNTL-FITC was incubated with neutrophils under specified conditions and quantified in the supernatant as described in Materials and Methods.
The incubation conditions and the results are shown in Table 2. In the control experiments the labeled peptide was incubated in the buffer without cells. After $10 \mathrm{~min}$ of incubation of cells with $20 \mathrm{nM}$ or $1 \mu \mathrm{M}$ fMLP, depletion of ligand occurred in the HDS but not LDS. There was no loss of $1 \mathrm{nM}$ fMLP in either HDS or LDS.

Experiments with FNLPNTL-FITC showed that it may be more readily lost than fMLP. FNLPNTL-FITC initially present at $1 \mu \mathrm{M}$ was markedly depleted (by $65 \%$ ) in 10 min by $\mathrm{HDS}$ at $25^{\circ} \mathrm{C}$, and some depletion (10-24\%) was found even in LDS both at $25^{\circ} \mathrm{C}$ and $15^{\circ} \mathrm{C}$. In the perfusion experiment the depletion was noticeable at the beginning of the perfusion, when the cell concentration was still high, although the level recovered with $5 \mathrm{~min}$ of perfusion. With a lower FNLPNTL-FITC concentration $(0.1 \mathrm{nM})$ we invariably found loss of the fluorescence in the supernatant after incubation of the peptide with the high-density cell suspensions at $25^{\circ} \mathrm{C}$ and at $15^{\circ} \mathrm{C}$ but not with low-density suspensions. Taken together, these results suggest that neutrophil responses initiated by a onetime addition of FNLPNTL-FITC or high concentrations of fMLP into HDS may be influenced by loss of the active

TABLE 1. Effect of Experimental Conditions on the Actin Polymerization Response ${ }^{a}$

\begin{tabular}{lccccc}
\hline & \multicolumn{4}{c}{ Cell concentration $(1 / \mathrm{ml})$} \\
\cline { 2 - 6 } Stimulus & \multicolumn{1}{c}{$5 \times 10^{6}$} & $5 \times 10^{5}$ & $1 \times 10^{5}$ & $2 \times 10^{4}$ & Perfusion \\
\hline FNLPNTLFITC, 1nM & $48.6 \pm 2.0$ & $60.4 \pm 3.9$ & $61.5 \pm 2.8$ & $61.4 \pm 3.0$ & $66.5 \pm 4.8$ \\
FNLPNTLFITC, 0.02 nM & $1.2 \pm 1.15$ & $17.3 \pm 5.3$ & $22.7 \pm 5.4$ & $22.4 \pm 4.6$ & $31.4 \pm 4.8$ \\
fMLP, 50 nM & $35.4 \pm 6.6$ & $54.3 \pm 4.6$ & $56.3 \pm 5.4$ & $54.8 \pm 4.6$ & $61.4 \pm 5.2$ \\
fMLP, 0.5 nM & $7.3 \pm 1.5$ & $7.4 \pm 0.8$ & $8.1 \pm 2.7$ & $7.2 \pm 1.2$ & $8.3 \pm 1.2$
\end{tabular}

${ }^{a}$ The actin polymerization response (percent increase: mean $\pm \mathrm{SD}, n=3$ ) to the indicated concentrations of chemotactic peptides was determined at $5 \mathrm{~min}$. Bolus addition of the agonist was used with four different concentrations of cells and also under perfusion conditions, all at the same temperature, $24-25^{\circ} \mathrm{C}$. 
HP-FITC

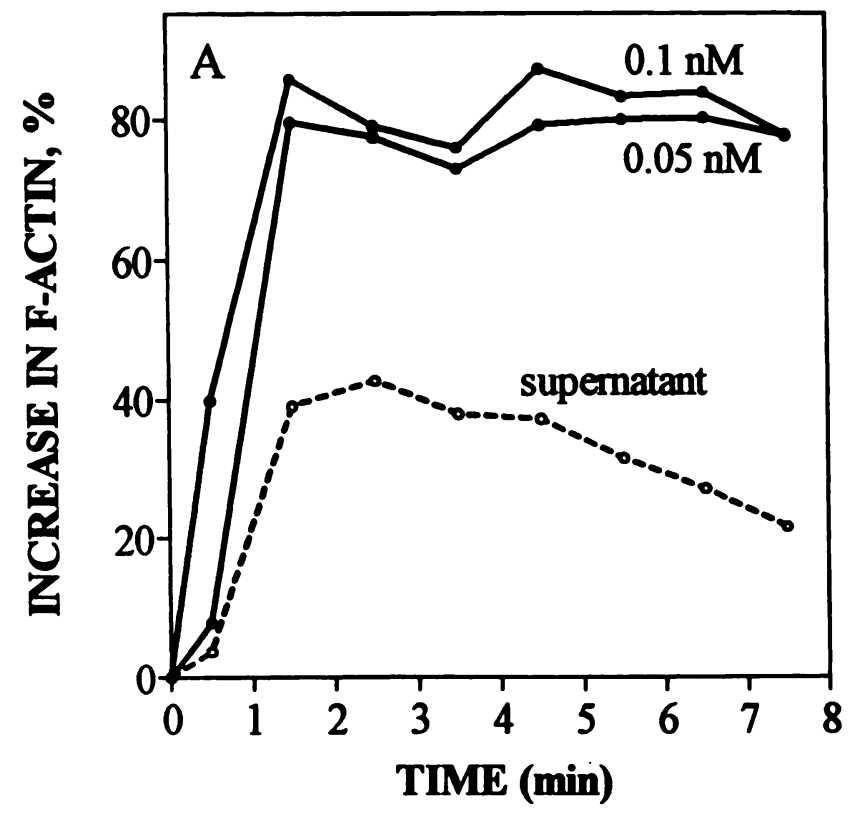

FMLP

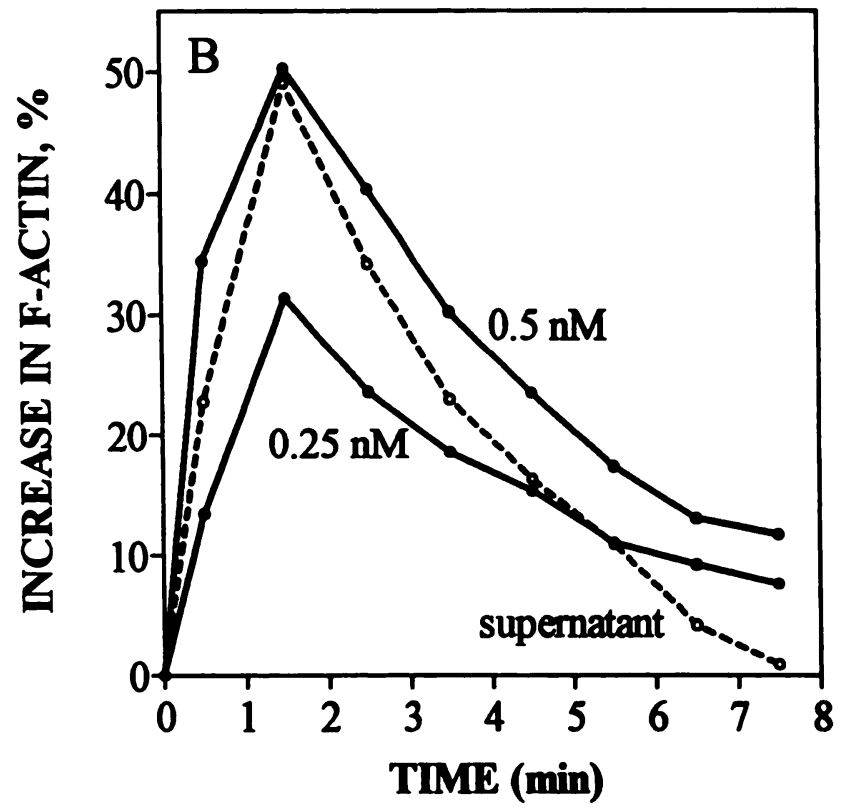

Fig. 3. Loss of biological activity of N-formyl peptides after preincubation with cells. Cells were stimulated with 0.1 nM FNLPNTL-FITC (A) and $0.5 \mathrm{nM}$ fMLP (B) for $10 \mathrm{~min}$; then the samples were centrifuged and the supernatant recovered. A fresh sample of cells was then perfused with the supernatant (dashed lines), and the actin polymerization response was measured as described in the text. The solid lines represent the controls, where the cells were perfused with the indicated concentrations of the peptides in buffer. The results were reproduced in two experiments.

agonist from solution. At the same time, fMLP appears not to be lost at low concentrations $(0.1 \mathrm{nM})$. The diminished activity of the supernatant from cells incubated with $0.5 \mathrm{nM}$ fMLP shown in Figure 3B could be attributed to inhibitory substances secreted by neutrophils during incubation and stimulation.

To test more directly whether an inhibitor of cell activation accumulated in the extracellular medium, a cell supernatant was generated by an 8-min incubation of HDS at $25^{\circ} \mathrm{C}$ with subsequent 8-min stimulation with 0.4 nM AMLP and also by a 16-min incubation of HDS without stimulation. After discarding the cells by centrifugation, additional $\mathrm{fMLP}$ was added to the supernatant to bring its final concentration to $4.4 \mathrm{nM}$. Even if some loss of the previously added $0.4 \mathrm{nM}$ fMLP had occurred, the resulting uncertainty in the final fMLP concentration would have been negligible. This solution of AMLP in the supernatant was tested for its activity in the perfusion experiment, which was analogous to the experiment described in the previous section (to increase the duration of this experiment, the flow rate was switched from 1 $\mathrm{vol} / \mathrm{min}$ to $0.5 \mathrm{vol} / \mathrm{min}$ at $5 \mathrm{~min}$ ). As a control, we used 4.4 $\mathrm{nM}$ fMLP in MGB in the same perfusion protocol. The results (Fig. 4) are consistent with those shown in Figure 3B in that the supernatant from both stimulated and unstimulated cells had little effect on the first $2 \mathrm{~min}$

TABLE 2. Loss of Chemotactic Peptides in the Course of Neutrophil Activation ${ }^{a}$

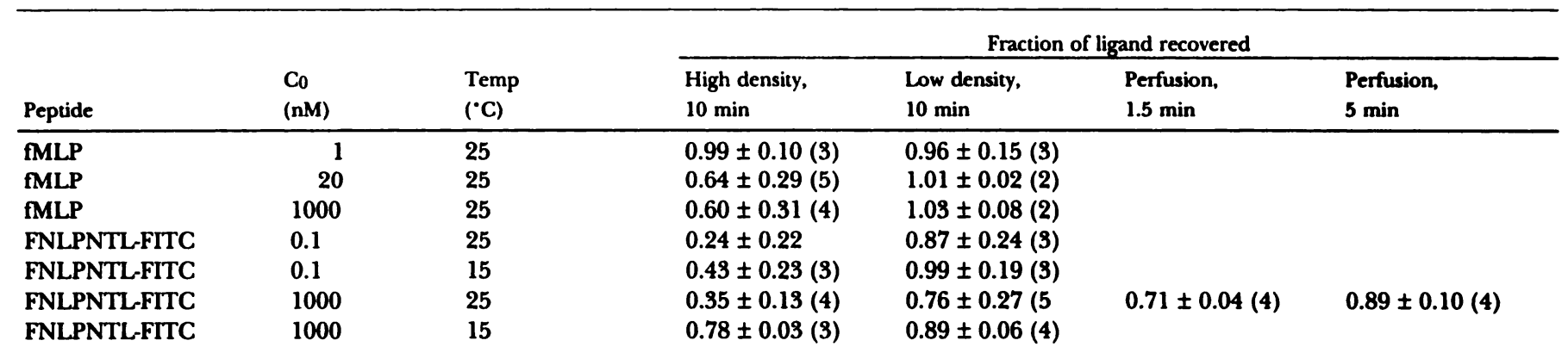

${ }^{a}$ The results (mean $\pm \mathrm{SD}$ ) are expressed as a ratio of the peptide remaining in the supernatant after activation of cells to a control incubation in the buffer with no cells. AMLP and high concentrations of FNLPNTL were measured after thin-layer chromatography and low concentrations of FNLPNTL were measured in the supernatant, as described in Materials and Methods. The measurements were done in duplicate for each experiment except for the experiments with 0.1 nM FNLPNTL-FITC, which were done in triplicate. The total numbers of experiments are shown in parentheses; $\mathrm{C}_{0}$ denotes the initial peptide concentration. The highest $\mathrm{AMLP}$ concentration ( $1 \mathrm{nM}$ ) was achieved by adding unlabeled fMLP to $20 \mathrm{nM}\left[{ }^{3} \mathrm{H}\right] \mathrm{HMLP}$. 


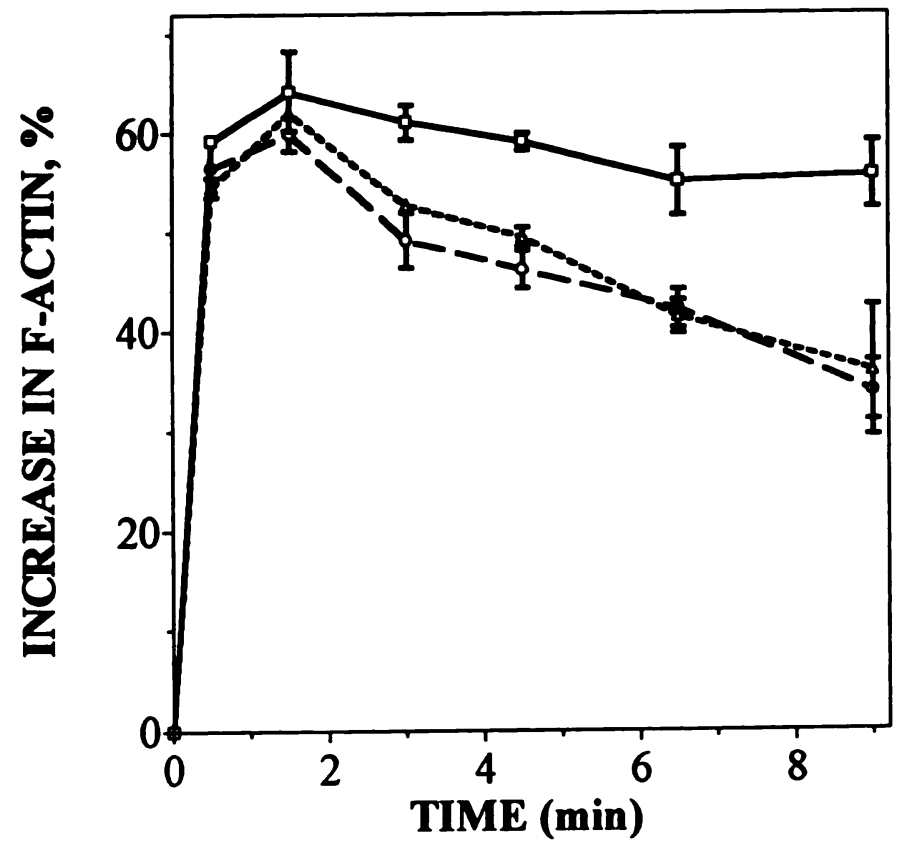

Fig. 4. Test for the release into the extracellular medium of an inhibitor of cell activation. Supernatant from cells $\left(5 \times 10^{6}\right.$ cells $\left./ \mathrm{ml}\right)$ incubated with (dashed line) or without (dotted line) $0.4 \mathrm{nM}$ fMLP for $16 \mathrm{~min}$ was collected. Additional fMLP was added to the supernatant to bring its final concentration to $4.4 \mathrm{nM}$. This supernatant was then used as perfusate for activating a second sample of cells in the perfusion protocol and the F-actin levels determined as in Materials and Methods. As a control, a sample of cells was perfused with $4.4 \mathrm{nM}$ fMLP in buffer (solid line). The bars show the standard deviation calculated on the basis of two experiments done with the same sample. The experiment was repeated four times.

of the response, but it accelerated the turnoff of the response at later times. This supported the hypothesis that products released by neutrophils can alter the response kinetics. Neutrophil activation is not required for the release of these inhibitory products.

Oxygen radicals and adenosine are important but not the only factors contributing to response inhibition

We undertook a series of experiments to verify the importance of some of the previously described factors in response inhibition: the phosphoramidon-sensitive proteolytic cleavage of $\mathrm{MLP}$ [37], the oxidation of AMLP by the myeloperoxidase $-\mathrm{H}_{2} \mathrm{O}_{2}$ system [38] or, rather, through any reaction with the involvement of $\mathrm{O}_{2}{ }^{-}$and $\mathrm{H}_{2} \mathrm{O}_{2}$, and the response inhibition by adenosine in the medium [26]. We used $0.1 \mu \mathrm{M}$ phosphoramidon to in- hibit the protease, $0.05 \mathrm{mg} / \mathrm{ml}$ SOD with $0.1 \mathrm{mg} / \mathrm{ml}$ catalase to inactivate oxygen radicals, and $0.025 \mathrm{mg} / \mathrm{ml}$ adenosine deaminase to remove adenosine. These reagents were added to HDS, and the actin responses to $0.02 \mathrm{nM}$ FNLPNTL-FITC, $1 \mathrm{nM}$ FNLPNTL-FITC, or 50 nM $\mathrm{fMLP}$ were measured after $5 \mathrm{~min}$ of stimulation at $25^{\circ} \mathrm{C}$ (Table 3). For controls we used HDS without additives and LDS $\left(2 \times 10^{4}\right.$ cells $\left./ \mathrm{ml}\right)$. In a separate set of experiments we added both free radical scavengers (catalase and SOD) and adenosine deaminase to HDS and observed the response at four different time points (Fig. 5).

From data in Table 3 the following conclusions can be made: (1) None of the additions to HDS enhanced the response to $0.02 \mathrm{nM}$ FNLPNTL-FITC. Most likely in HDS, but not LDS, free ligand is depleted due to binding to the receptors (see Discussion). (2) Phosphoramidon did not enhance the response to fMLP and, as the pairwise $t$-test showed, even inhibited the response to $1 \mathrm{nM}$ FNLPNTL FITC $(P<.03)$. Previous authors also did not detect any effect of phosphoramidon on the right-angle light scattering, a parameter closely related to actin polymerization [22]. It seems possible from these data that, even though phosphoramidon may offer some protection to fMLP, this effect is counterbalanced by an inhibitory action of phosphoramidon itself. (3) Free radical scavengers significantly enhanced the response to $50 \mathrm{nM}$ fMLP but not to $1 \mathrm{nM}$ FNLPNTL-FITC. This is possibly related to the presence of methionine in fMLP, which is an easy target of oxygen radicals. (4) The removal of adenosine from solution brought the response at a 5-min point close to that in the low-density suspension. However, a more detailed study (Fig. 5) showed that even a combined action of catalase, SOD, and adenosine deaminase failed to mimic completely the LDS conditions. Factors other than oxidants and adenosine may be present in HDS and inhibit the response. It is worth mentioning, though, that complete actin depolymerization by 5 min, observed with some of the HDS samples after stimulation with FMLP, never occurred in the presence of adenosine deaminase and antioxidation enzymes.

\section{Qualitative characteristics of the enhanced response}

Having determined that LDS provides the optimal conditions for measuring response kinetics by preventing ligand depletion and accumulation of inhibitors, we characterized the kinetics of the actin response in LDS. Examples of the kinetic curves in LDS at $25^{\circ} \mathrm{C}$ are shown in Figure 6; Figures 2-4 demonstrate some results of stimulation by perfusion. At high concentrations of the peptides that gave maximal responses, the actin polymeri-

TABLE 3. Effect of Additions in the Incubation Medium on the Actin Polymerization Response ${ }^{a}$

\begin{tabular}{|c|c|c|c|}
\hline & $\begin{array}{c}\text { FNLPNTL-FTTC } \\
(1 \mathrm{nM})\end{array}$ & $\begin{array}{c}\text { FNLPNTLFITC } \\
(0.02 \mathrm{nM})\end{array}$ & $\begin{array}{l}\text { RMLP } \\
(50 \mathrm{nM})\end{array}$ \\
\hline HDS & $38.6 \pm 17.3(5)$ & $-2.9 \pm 6.6(3)$ & $5.2 \pm 16.5(5)$ \\
\hline HDS/phosphoramidon & $25.4 \pm 18.5(3)$ & $-4.6 \pm 5.1(3)$ & $2.3 \pm 22.9(3)$ \\
\hline HDS/catalase/SOD & $41.8 \pm 13.0(5)$ & $1.1 \pm 5.5(3)$ & $43.6 \pm 11.2(5)$ \\
\hline HDS/adenosine deaminase & $62.3 \pm 7.3(4)$ & $-0.9 \pm 5.0(3)$ & $54.3 \pm 10.7(4)$ \\
\hline LDS & $57.6 \pm 16.5(6)$ & $22.7 \pm 11.7(3)$ & $60.5 \pm 16.9(6)$ \\
\hline
\end{tabular}

${ }^{a}$ Cells were prepared as LDS $\left(2 \times 10^{4}\right.$ cells $\left./ \mathrm{ml}\right)$ or HDS. The additions to the high-density suspensions were either $0.1 \mathrm{mM}$ phosphoramidon, $0.1 \mathrm{mg} / \mathrm{ml}$ catalase with $0.05 \mathrm{mg} / \mathrm{ml} \mathrm{SOD}$, or $0.025 \mathrm{mg} / \mathrm{ml}$ adenosine deaminase. The actin response (percent increase: mean \pm SD) was measured after 5 min of stimulation at $25^{\circ} \mathrm{C}$. The numbers of repeats are given in parentheses. 


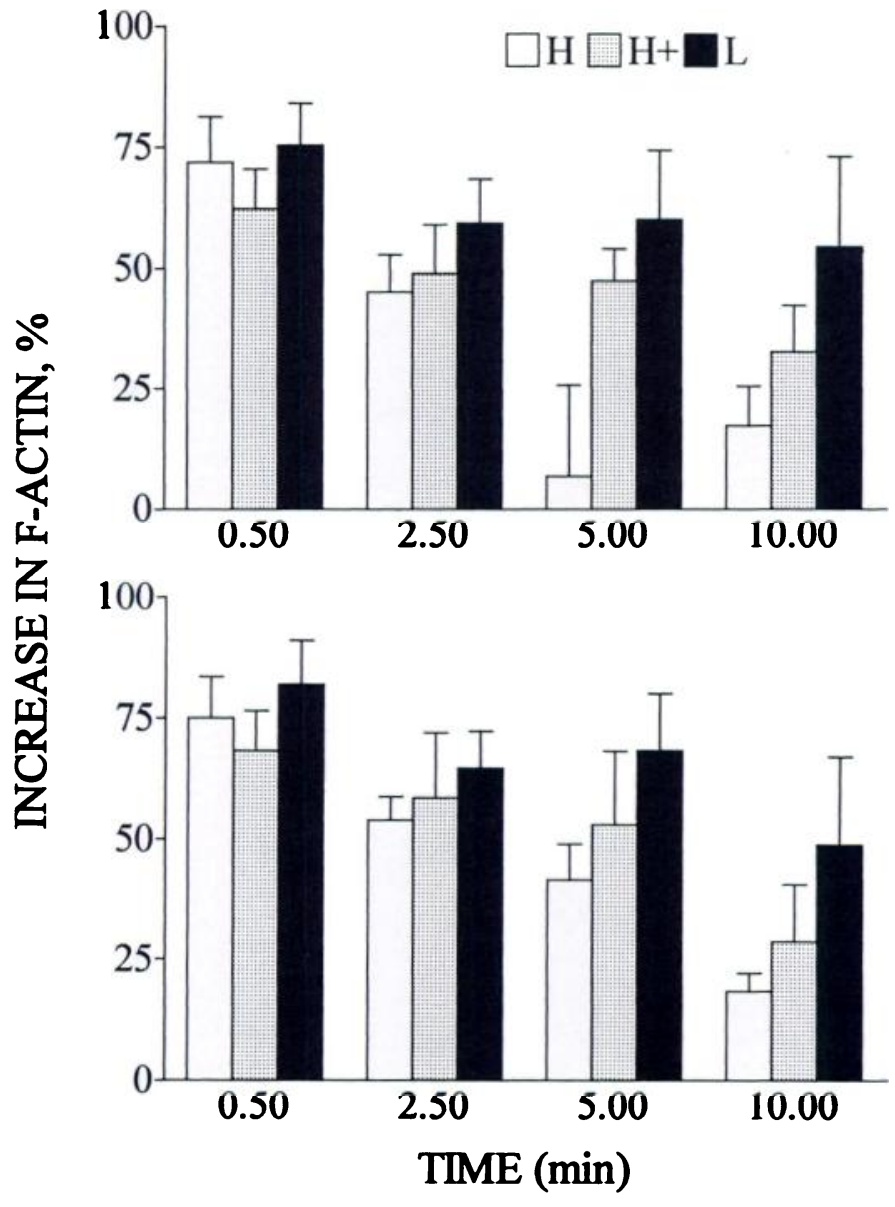

Fig. 5. Effect of SOD, catalase, and adenosine deaminase on the actin polymerization response to fMLP and FNLPNTL-FITC. Cells were stimulated with $50 \mathrm{nM}$ fMLP (top) and $1 \mathrm{nM}$ FNLPNTL-FITC (bottom) in HDS with $\left(\mathrm{H}^{+}, n=4\right)$ or without $(\mathrm{H}, n=5)$ SOD + catalase + adenosine deaminase (concentrations were the same as in Table 3). For comparison, the response of cells in LDS $(L, n=6)$ was also determined. Activation was done at $25^{\circ} \mathrm{C}$.

zation response often reached a level where it stayed nearly constant for at least several minutes. The kinetics were similar for fMLP and FNLPNTL-FITC. When low peptide concentrations were used, the response to FNLPNTL-FITC developed more slowly than to fMLP. At these suboptimal concentrations, the peaks of polymerization occurred with FNLPNTL-FITC at 50-70 $\mathrm{s}$ and with fMLP at $20-30 \mathrm{~s}$ at $25^{\circ} \mathrm{C}$, and at $15^{\circ} \mathrm{C}$ the peaks were, respectively, at 4-5 $\mathrm{min}$ and 1.5-2 $\mathrm{min}$ (detailed data not shown). We hypothesized that these differences in kinetics reflected different binding rates of the two peptides. During the early part of the response the rate of binding is approximately proportional to the product of $\boldsymbol{k}_{\text {on }}$ and agonist concentration. There are no published data for $k_{\text {on }}$ of $\mathrm{MLLP}$. If it is high enough, then at peptide concentrations that produce comparable responses, the product of the association rate and peptide concentration may be greater for fMLP than for FNLPNTL-FITC. Then it is likely that faster fMLP binding would produce a faster response. However, at sufficiently high concentrations of the peptides, binding of both FMLP and FNLPNTL is so rapid that factors other than binding become rate limiting, and the differences between the responses to the two peptides disappear.
To prove experimentally that the binding rates were responsible for the kinetic differences at low agonist concentrations, we modified the stimulation conditions: the agonists were incubated with $2.5 \times 10^{5}$ cells $/ \mathrm{ml}$ on ice for $30 \mathrm{~min}$ to allow the ligands to bind to the receptors without activating the cellular responses. To initiate the actin polymerization response, an aliquot of the cell suspension was transferred into a nine times larger volume of buffer at $16-17^{\circ} \mathrm{C}$. This temperature was chosen to avoid too drastic changes that could by themselves cause major actin polymerization and, on the other hand, to reveal all the characteristic features of the response kinetics. For comparison, the analogous experiment was performed with cells incubated for $30 \mathrm{~min}$ on ice without agonist. As shown in Figure 7, the kinetics of the responses to fMLP and FNLPNTLFITC became identical when the transition period from zero to equilibrium receptor occupancy was eliminated.

\section{Conversion of the receptors into a slowly dissociating form is unaffected by cell density}

Termination of the response has been associated with conversion of the receptors to a state characterized by a low dissociation rate. Using FNLPNTL-FITC, Sklar et al. [35] showed that after short binding times dissociation included rapidly and slowly dissociating forms. After long binding times, only the slowly dissociating form was present. Because by that time the responses to the chemoattractant had subsided, it was concluded that the slowly dissociating receptors do not participate in the signal transduction. For these experiments, cells were generally kept at a concentration of $10^{7} \mathrm{ml}^{-1}$; it was therefore important to know whether the enhanced response we observed under the LDS conditions in our experiments was due to lack of conversion of receptors to the slowly dissociating form. Cells in LDS at $25^{\circ} \mathrm{C}$ were allow to bind

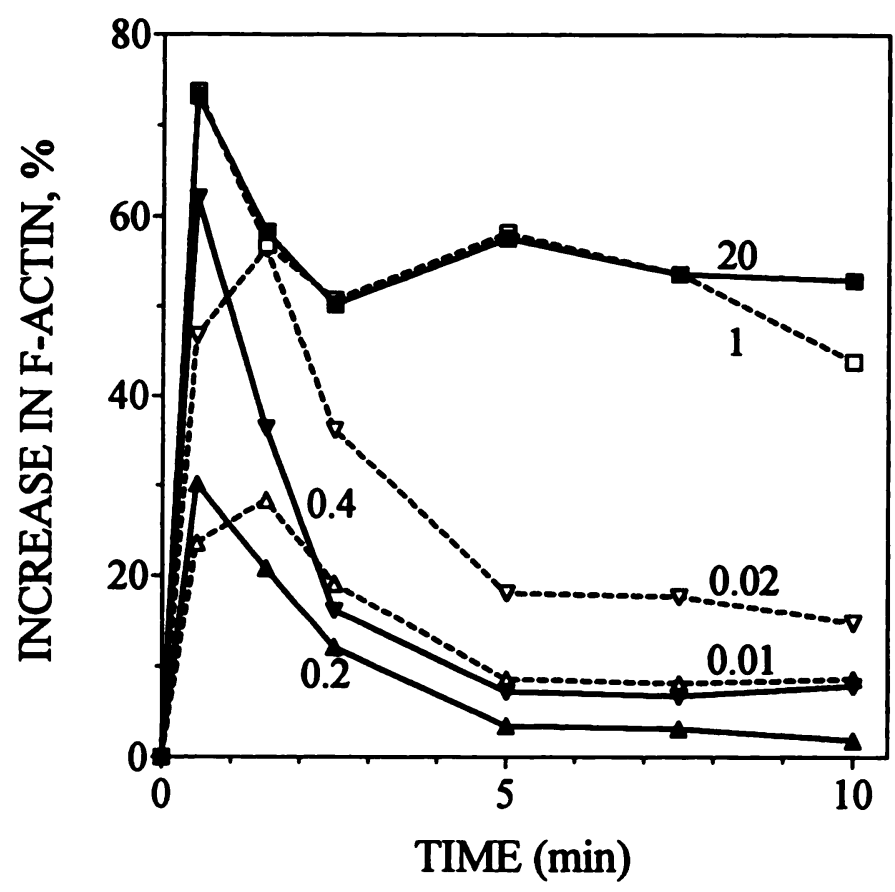

Fig. 6. Kinetics of the actin polymerization response in LDS. Cells at 5 $\times 10^{8} / \mathrm{ml}$ were stimulated at $25^{\circ} \mathrm{C}$ with agonist and $\mathrm{F}$-actin was quantified as described in Materials and Methods. Concentrations of MLP (solid line) and FNLPNTL-FITC (dashed line) are given in $\mathrm{nM}$. 
NOT PREBOUND

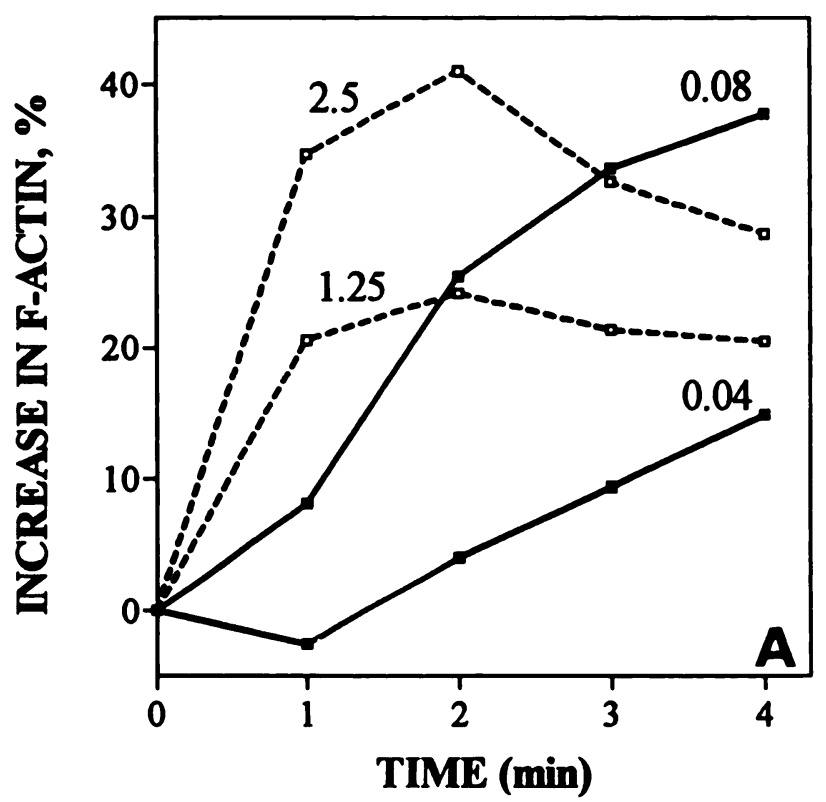

PREBOUND

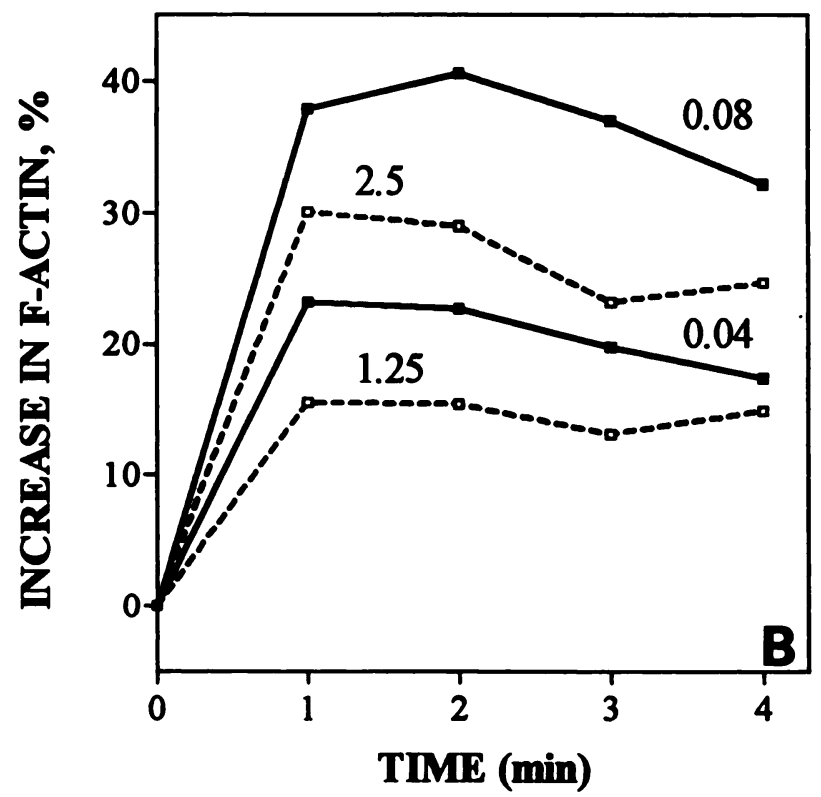

Fig. 7. Effect of prebound ligand on the actin polymerization response kinetics. Neutrophils at $2.5 \times 10^{5}$ cells $/ \mathrm{ml}$ were kept on ice for $30 \mathrm{~min}$ with agonist (B) to allow it to bind to receptors before activation and without agonist (A). Activation of the actin polymerization response was initiated by transferring one volume of the cell suspension into nine volumes of buffer at $16^{\circ} \mathrm{C}$ with the same concentration of the agonist. Dashed lines represent AMLP and solid lines represent FNLPNTL-FITC at concentrations indicated in nM. Control cells kept on ice for $30 \mathrm{~min}$, then diluted into $16^{\circ} \mathrm{C}$ buffer without agonist showed no change in $\mathrm{F}$-actin levels. The experiment was done twice.

$2.5 \mathrm{nM}$ FNLPNTLFITC for 0.5 or $10 \mathrm{~min}$, and the dissociation of the peptide was observed with the flow cytometer as the decrease in cell-associated fluorescence after adding a high concentration of AMLP (Fig. 8). After 0.5 min of binding, both rapid and slow dissociation components were present, but only the slow one remained after $10 \mathrm{~min}$ of binding. Similar results were obtained with HDS [35]; we therefore conclude that keeping cells at a low concentration does not prevent the agonist-induced receptor conversion into the slowly dissociating form. The fact that this conversion occurs under LDS conditions, when the cell response is sustained, suggests either that the slowly dissociating form of the receptor is signaling or that a small number of rapidly dissociating, active receptors exist at long times that are not detectable by the method employed.

\section{DISCUSSION}

Kinetics of cellular responses can be studied under different conditions. If one is interested in the turnoff due to intrinsic cellular mechanisms, it seems natural to perform a continuous stimulation experiment keeping the external ligand concentration constant and having a buffer free from cellular products.

It is known that new $N$-formyl peptide receptors must be activated to maintain the response [39]. Therefore, if the concentration of free agonist drops, one should expect that cellular responses would be affected. The data in Table 2 demonstrate that the condition of constant agonist concentration is not satisfied for a bolus injection of high concentrations of FNLPNTLFITC or AMLP if the cell density in the medium is high. At low agonist concentrations, FNLPNTL-FITC but not fMLP was lost from the supernatant. This may reflect their different affinities for the receptors. Neutrophils at a concentration of $5 \times 10^{6}$ cells/ml may supply $0.5 \mathrm{nM}$ or more receptors for $N$-formyl peptides [35]. High-affinity FNLPNTL-FITC with $K_{d}$ $=0.5 \mathrm{nM}$ [35], initially present in the medium at a concentration of $0.5 \mathrm{nM}$ or less, at equilibium will be depleted at least by half due to binding to $0.5 \mathrm{nM}$ receptors. At the same time, fMLP with $K_{d}=20 \mathrm{nM}$ [40] will remain almost entirely in solution. The lack of any effect of adenosine deaminase and antioxidants on the response to a low FNLPNTL-FITC concentration (Table 3) also indirectly supports this conclusion.

At higher $\mathrm{N}$-formyl peptide concentrations, other factors come into play. On the average, $40 \%$ of $\left[{ }^{3} \mathrm{H}\right] \mathrm{fMLP}$ and $65 \%$ of FNLPNTL-FITC was lost from the solution after a 10 -min incubation with $5 \times 10^{6}$ cells $/ \mathrm{ml}$ at $25^{\circ} \mathrm{C}$. The FNLPNTL-FITC-containing solution also underwent a dramatic loss of biological activity. Other authors have shown that, under conditions promoting degranulation, neutrophils can oxidize fMLP at the methionine moiety, converting it into a chemotactically inactive product [38]. Myeloperoxidase was found to be a catalyst of this oxidation reaction. Other known reactions, by which fMLP can be inactivated, are hydrolysis by a membrane peptidase $[28,41]$, which can be inhibited by phosphoramidon [37, 42], and lysosomal digestion [43]. Proteolytic involvement in the destruction of the hexapeptide by neutrophils has also been suggested [44]. Our data confirm that oxygen products play an important role in the inactivation of fMLP. It is not clear if we observed the same reaction as the previous authors did [38], since it is unlikely that 

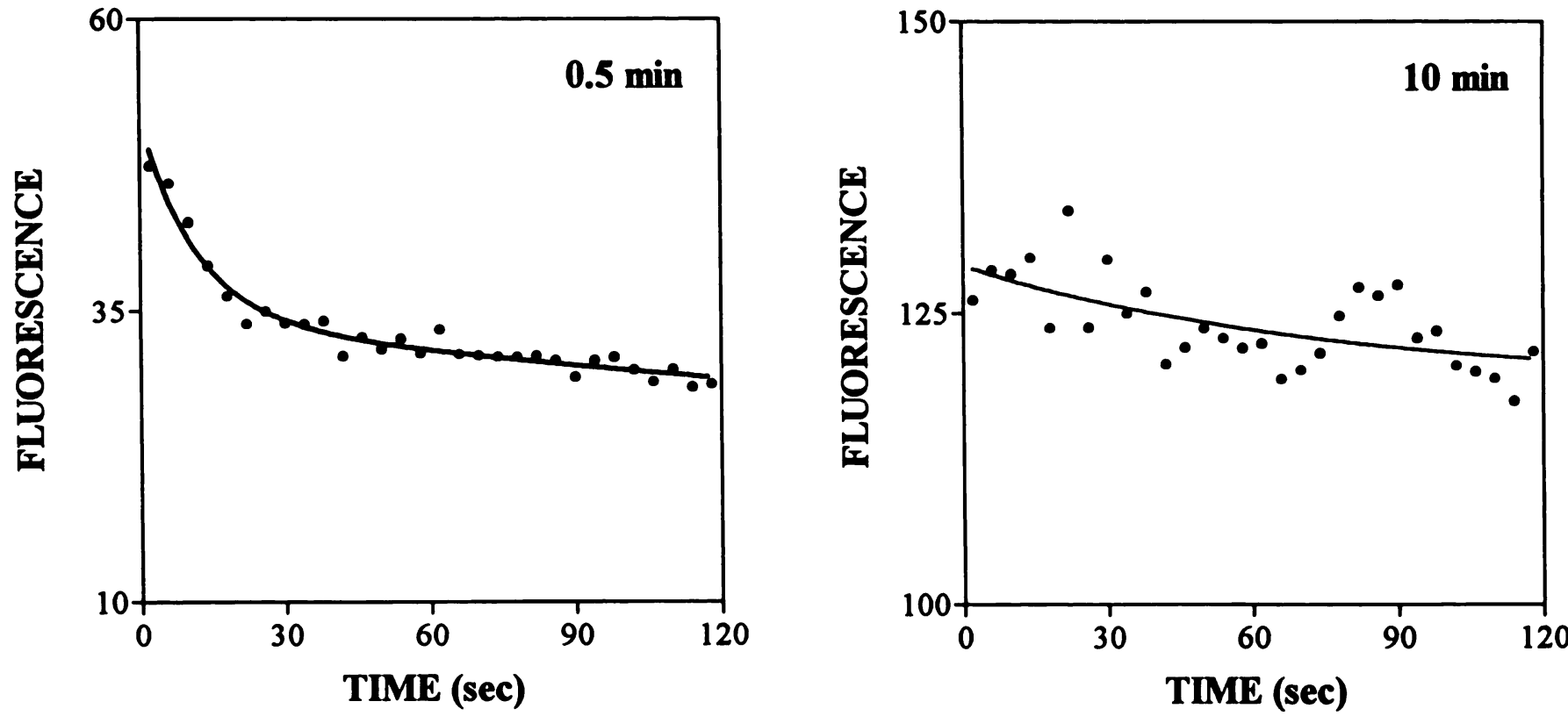

Fig. 8. Dissociation of FNLPNTL-FITC from neutrophils after it was allowed to bind for $0.5 \mathrm{~min}$ and $10 \mathrm{~min}$ at $25^{\circ} \mathrm{C}$. The vertical scale shows the mean fluorescence channel determined as described in Materials and Methods, and the horizontal scale shows the time after addition of 0.1 mM fMLP to prevent further binding of FNLPNTL-FITC. Results obtained with the same neutrophil preparation are shown, the dots representing the duplicate runs for one experiment. The lines represent the best fit of a two-state dissociation after 0.5 min of binding and one-state dissociation after $10 \mathrm{~min}$ of binding. The experiment was done twice.

significant degranulation occurred in the conditions of our experiments. It is possible that proteolytic enzymes (phosphoramidon insensitive) contribute to the loss of FNLPNTL-FITC at high concentration.

Our results also imply that a cell-mediated modification of the medium is another factor that is responsible for the difference between HDS and LDS/perfusion experiments. A slowly acting inhibitory activity present in the supernatant from unstimulated cells and from cells stimulated with a low dose of AMLP (Figs. 3B and 4) is reminiscent of the delayed action of forskolin, a cAMP-elevating agent [45]. Adenosine is another compound that raises the cellular cAMP level and can inhibit chemoattractantinduced responses $[26,46]$. By incubating the cells with adenosine deaminase, we were able to bring the actin response close to that in the low-density suspension.

The majority of the previously published results on the response kinetics were obtained using concentrated cell suspensions. Moreover, protective substances like BSA, which not only reduces nonspecific binding but also scavenges free radicals [47], were usually not included in the buffer. Therefore it seems possible that some of the reports of rapid desensitization of neutrophils partly reflected the loss of the active agonist and the presence of adenosine and perhaps some other inhibitory components in the medium.

Keeping cells at a low density appears to be an approximation of the desired experimental conditions: a nearly constant concentration of the agonist and the medium minimally contaminated with cellular products. The perfusion method probably achieves a clearer medium at late times, but certainly not at the beginning, when the cell concentration is still high. Kinetics of the actin polymerization response were obtained using both methods. Perfusion often resulted in a somewhat stronger response at late times, although the main features of the kinetics obtained with the two methods were similar. First, using high agonist concentrations, we were able to stimulate a strong and nondecaying response lasting at least 7-10 min. This contrasts with the majority of the published results (a possibility of a long-lasting actin polymerization stimulated by a chemotactic peptide has been mentioned occasionally [48]). Interestingly, a 10-min incubation of neutrophils with chemotactic peptides at $25^{\circ} \mathrm{C}$ converted most of the fMLP receptors into a slowly dissociating state (Fig. 8) which was thought to represent an inactive receptor form $[10,12,35]$. Recent data showing that formation of the receptor-cytoskeleton complex does not preclude the degranulation response [19] called for modification of this view. Our results also do not support the interpretation of the slowly dissociating receptors as totally inactive, although we cannot rule out the possibility that a small number of rapidly dissociating receptors undetectable by our methods were present after 10 min of binding.

A significant response turnoff occurred, however, at low doses of the ligand (Fig. 7). This was especially evident with activation by $\mathrm{fMLP}$, since perfusion with low concentrations of FNLPNTLFITC sometimes resulted in an almost nondecaying response. The difference between the peptides could be due to a slower binding of FNLPNTL-FITC. Our measurements of equilibrium FNLPNTL-FITC binding on ice (data not shown) verified the earlier finding of other authors [7] that receptor down-regulation was not an important factor under these conditions. Phosphorylation of the $\mathrm{N}$-formyl peptide receptors induced by fMLP was demonstrated in HL60 cells, which are closely related to neutrophils [14], and rat basophilic leukemia cells transfected with fMLP receptor [15]. Although obtained with different cell types, the dose dependence of the receptor phosphorylation suggests that it may not be an important mechanism of response turn-off at low ligand concentrations (a 30-min incubation with $1 \mathrm{nM}$ fMLP produced almost no phosphorylation of the receptors in HL60 cells [14], and similar results were 
obtained with transfected cells [15]). The strongest evidence suggesting that the receptors are not desensitized by low agonist concentrations comes, however, not from the lack of documented receptor desensitization mechanisms acting at low agonist concentrations but from direct demonstration of their functioning. Bellavite et al. [49] showed that incubation with low nanomolar and subnanomolar concentrations of AMLP does not desensitize but, in contrast, primes neutrophils for increased superoxide production and degranulation in response to a second stimulation with a high dose of fMLP. Thus at least at the level of the receptors and $G_{i}$ proteins, whose activation is necessary for actin polymerization and also for the superoxide and degranulation responses, the signaling appears to be unimpaired. If this is so, desensitization of the actin response at low agonist concentrations occurs at a level beyond $G_{i}$ proteins. Of possible relevance to desensitization may be the fact that by the time the actin polymerization response subsided, neutrophils acquire a polarized shape with asymmetrically distributed components [50]. We hypothesize elsewhere (M.A. Model and G.M. Omann, in preparation) that cell polarization might act as a desensitization factor. At any rate, the transient nature of the response to a weak stimulation could be due only to processes that are themselves activated by a weak stimulation.

\section{ACKNOWLEDGMENTS}

This work has been discussed with Drs. David Aminoff, Daniel Axelrod, and Richard Neubig. Dr. Paul Weinhold gave us helpful advice on TLC techniques and Dr. Jorge Gumucio kindly provided the infusion pump. The majority of neutrophil preparations were done by Michael Keil. The authors are grateful to all these persons. The work was supported by a VA Merit Grant to G.M.O., a University of Michigan Department of Surgery RAC Grant, NIH Training Grant GM08270-07 (Molecular Biophysics), and a University of Michigan Rackham Research Partnership award.

\section{REFERENCES}

1. Wheeler, J.G., Abramson, J.S., Quie, P.G. (1989) Polymorphonuclear leukocytes-the neutrophil. In Natural Immunity (D.S. Nelson, ed), Academic Press, Sydney, Australia, 39-70.

2. O'Flaherty, J.T., Kreutzer, D.L., Showell, H.J., Vitkauskas, G., Becker, E.L., Ward, P.A. (1979) Selective neutrophil desensitization to chemotactic factors. J. Cell Biol. 80, 564-572.

3. Simchovitz, L., Atkinson, J.P., Spilberg, I. (1980) Stimulus-specific deactivation of chemotactic factor-induced cAMP response and superoxide production in human neutrophils. J. Clin. Invest. 66, 736-747.

4. English, D., Roloff, J.S., Lukens, J.N. (1981) Regulation of human polymorphonuclear leukocyte superoxide release by cellular responses to chemotactic peptides. J. Immunol. 126, 165-171.

5. Sha'afi, R.J., Molski, T.F.P., Borgeat, P., Naccache, P.H. (1981) Deactivation of the effects of $\mathrm{f}-\mathrm{Met}-\mathrm{Leu}-\mathrm{Phe}$ and leukotriene $\mathrm{B}_{4}$ on calcium mobilization in rabbit neutrophils. Biochem. Biophys. Res. Commun. 103, 766-773.

6. Donabedian, H., Gallin, J.I. (1981) Deactivation of human neutrophil chemotaxis by chemoattractants: effect on receptors for the chemotactic factor f-Met-Leu-Phe. J. Immunol. 127, 839-844.

7. Sullivan, S.J., Zigmond, S.H. (1980) Chemotactic peptide receptor modulation in polymorphonuclearleukocytes.J. CellBiol.85, 703-711.

8. Wilde, M.W., Carlson, K.E., Manning, D.R., Zigmond, S.H. (1989) Chemoattractant-stimulated GTPase activity is decreased on membranes from polymorphonuclear leukocytes incubated in chemoattractant. J. Biol Chem. 264, 190-196.

9. McLeish, K.R., Giershik, P., Jakobs, K.H. (1989) Desensitization uncouples the formyl peptide receptor-guanine nucleotide binding protein interaction in HL60 cells. Mol. Pharmacol. 36, 384-390.

10. Jesaitis, A.J., Naemura, J.R., Sklar, L.A., Cochrane, C.G., Painter, R.G. (1984) Rapid modulation of $N$-formyl chemotactic peptide receptors on the surface of human granulocytes: formation of high-affinity ligand-receptor complexes in transient association with cytoskeleton. Y. Biol. Chem. 98, 1378-1387.

11. Särndahl, E., Bokoch, G.M., Spicher, K., Stendahl, O., Andersson, T. (1991) G-proteins and the association of ligand/receptor complexes with the cytoskeleton in human neutrophils. Biochem. Soc. Trans. 19, 1127-1129.

12. Klotz, K.-N., Krotec, K., Gripentrog, J., Jesaitis, A. (1994) Regulatory interaction of $N$-formyl peptide chemoattractant receptors with the membrane skeleton in human neutrophils. J. Immunol. 152 , 801-810.

13. Jesaitis, A.J., Bokoch, G.M., Tolley, J.O., Allen, R.A. (1988) Lateral segregation of neutrophil chemotactic receptors into actin- and fodrin-rich plasma membrane microdomains depleted in guanyl nucleotide regulatory proteins. J. Cell Biol. 107, 921-928.

14. Tardif, M., Mery, L., Brouchon, L., Boulay, F. (1993) Agonist-dependent phosphorylation of $\mathrm{N}$-formylpeptide and activation peptide from the fifth component of $\mathrm{C}$ (C5a) chemoattractant receptors in differentiated HL60 cells. J. Immunol. 150, 3534-3545.

15. Ali, H., Richardson, R.M., Tomhave, E.D., Didsbury, J.R., Snyderman, R. (1993) Differences in phosphorylation of formylpeptide and C5a chemoattractant receptors correlate with differences in desensitization. J. Biol Chem. 268, 24247-24254.

16. Montero, M., García-Sancho, J., Alvarez, J. (1994) Phosphorylation down-regulates the store-operated $\mathrm{Ca}^{2+}$ entry pathway of human neutrophils.J. Biol. Chem. 269, 3963-3967.

17. Johnston, J.A., Ferris, D.K., Wang, J.M., Longo, D.L., Oppenheim, J.J., Kelvin, D.J. (1994) Staurosporin restores signaling and inhibits interleukin-8-induced chemotactic desensitization. Eur. J. Immunol 24, 2556-2562.

18. Lee, G.-H.D., Kaptein, J.S., Scott, S.J., Niedzin, H., Kalunta, C.I., Lad, P.M. (1989) Desensitization of calcium mobilization and cell function in human neutrophils. Biochem. J. 262, 165-172.

19. Lundqvist, H., Gustafsson, M., Johansson, A., Särndahl, E., Dalgren, C. (1994) Neutrophil control of formylmethionyl-leucyl-phenylalanine induced mobilization of secretory vesicles and NADPH-oxidase activation: effect of an association of the ligand-receptor complex to the cytoskeleton. Biochim. Biophys. Acta 1224, 43-50.

20. Akard, L.P., English, D., Gabig, T.G. (1988) Rapid deactivation of NADPH oxidase in neutrophils: continuous replacement by newly activated enzyme sustains the respiratory burst. Blood 72, 322-327.

21. Mizunari, H., Kuratsuji, T., Namiki, H., Tsunawaki, S. (1994) Activation of respiratory burst oxidase is accompanied by desensitization of $\mathrm{p}^{4 \text { phox }}$ in nucleoside-triphosphate binding along with its translocation to cell membrane. Biochem. Biophys. Res. Commun. 198, 191-199.

22. Sklar, L.A., Omann, G.M., Painter, R.G. (1985) Relationship of actin polymerization and depolymerization to light scattering in human neutrophils: dependence on receptor occupancy and intracellular $\mathrm{Ca}^{*+}$.J. Cell Biol 110, 1161-1166.

23. Downey, G.P., Chan, C.K., Trudel, S., Grinstein, S. (1990) Actin assembly in electropermeabilized neutrophils: role of intracellular calcium. J. Cell Biol. 110, 1975-1982.

24. Xing, Z., Jordana, M., Kirpalani, H., Driscoll, K.E., Schall, T.J., Gauldie, J. (1994) Cytokine expression by neutrophils and macro phages in vivo: endotoxin induces tumor necrosis factor- $\alpha$, macro phage inflammatory protein-2, interleukin-1 $\beta$, and interleukin- 6 but not RANTES or transforming growth factor- $\beta_{1}$ mRNA expression in acute lung inflammation. Am. J. Respir. Cell MoL Biol. 10, 148-153.

25. Zurier, R.B. (1976) Prostaglandin release from human polymorphonuclear leukocytes. Adv. Prostaglandin Thromboxane Res. 2, 815-818.

26. Cronstein, B.N., Kramer, S.B., Wessman, G., Hirschhorn, R. (1983) Adenosine: a physiological modulator of superoxide anion generation by human neutrophils. J. Exp. Med 158, 1160-1177.

27. McDonald, P.P., McColl, S.R., Braquet, P., Borgeat, P. (1994) Autocrine enhancement of leukotriene synthesis by endogenous leukotriene $\mathrm{B}_{4}$ and platelet-activating factor in human neutrophils. Br.J. Pharmacol. 111, 852-860.

28. Bokoch, G.M. (1990) Signal transduction by GTP binding proteins during leukocyte activation: phagocytic cells. Curr. Top. Membr. Trans. 35, 65-101.

29. Aswanikumar, S., Shiffman, E., Corcoran, B.A., Wahl, S.M. (1976) Role of a peptidase in phagocyte chemotaxis. Proc. Nath Acad. Sci. USA 73, 2439-2442.

30. van Kessel, K.P., van Strijp, J.A., Verhoef, J. (1991) Inactivation of recombinant human necrosis factor- $\alpha$ by proteolytic enzymes released from stimulated human neutrophils. J. Immunol 147, 3862-3868.

31. Wallace, P.J., Wersto, R.P., Packman, C.H., Lichtman, M.A. (1984) Chemotactic peptide-induced changes in neutrophil actin conformation. J. Cell Biol. 99, 1060-1065.

32. Tolley, J.O., Omann, G.M., Jesaitis, A.J. (1987) A high-yield, high-purity method for preparing human granulocytes demonstrating en- 
hanced experimental lifetimes. J. Leukoc. Biol. 42, 43-45.

33. Howard, T.H., Meyer, W.H. (1984) Chemotactic peptide modulation of actin assembly and locomotion in neutrophils.J. Cell Biol. 98, 1265-1271.

34. Hayslett, H.T., Jr. (1968) Statistics Made Simple. Doubleday, Garden City, NY, 126.

35. Sklar, L.A., Finney, D.A., Oades, Z.G., Jesaitis, A.J., Painter, R.G., Cochrane, C.G. (1984) The dynamics of ligand-receptor interactions. J. Biol. Chem. 259, 5661-5669.

36. Sklar, L.A., Oades, Z.G., Jesaitis, A.J., Painter, R.G., Cochrane, C.G. (1981) Fluoresceinated chemotactic peptide and high-purity antifluorescein antibody as a probe of the temporal characteristics of neutrophil stimulation. Proc. Natl. Acad. Sci. USA 78, 7540-7544.

37. Painter, R.G., Dukes, R., Sullivan, J., Carter, R., Erdös, E.G., Johnson, A.R. (1988) Function of neutral endopeptidase on the cell membrane of human neutrophils. J. Biol. Chem. 263, 9456-9461.

38. Tsan, M.F., Denison, R. (1981) Oxidation of $\mathrm{N}$-formyl methionyl chemotactic peptide by human neutrophils. J. Immunol. 126, 1387-1389.

39. Sklar, L.A., Hyslop, P.A., Oades, Z.G., Omann, G.M., Jesaitis, A.J., Painter, R.G., Cochrane, C.G. (1985) Signal transduction and ligandreceptor dynamics in the human neutrophil. J. Biol. Chem. 260, 11461-11467.

40. Koo, C., Lefkowitz, R.J., Snyderman, R. (1982) The oligopeptide chemotactic factor receptor on human polymorphonuclear leukocyte membranes exists in two affinity states. Biochem. Biophys. Res. Commun. 106, 442-449.

41. Yuli, I., Snyderman, R (1986) Extensive hydrolysis of $N$-formylmethionyl-Lleu cyl- $\left.-{ }^{3} \mathrm{H}\right]$ phenylalanine by human polymorphonuclear leukocytes. J. Biol. Chem. 261, 4902-4908.
42. Connelly, J.C., Skidgel, R.A., Schulz, W.W., Johnson, A.R., Erdös, E.G. (1985) Neutral endopeptidase 24.11 in human neutrophils: cleavage of chemotactic peptide. Proc. Nath. Acad. Sci. USA 82, 8737-8741.

43. Nunoi, H., Endo, F., Chikazawa, S., Matsuda, I. (1985) Regulation of receptors and digestive activity toward synthesized formyl-chemotacticpeptide in human polymorphonuclear leukocytes. Blood 66, 106-114.

44. Niedel, J., Wilkinson, S., Cuatrecasas, P. (1979) Receptor-mediated uptake and degradation of ${ }^{123}$ I-chemotactic peptide by human neutrophils. I. Biol Chem. 254, 10700-10706.

45. Daniels, R.H., Bird, I.N., Hill, M.E., Finnen, M.J. (1993) Differential regulation of early phase and late phase responses in human neutrophils by cAMP. Biochem. Pharmacol. 45, 1613-1620.

46. lannone, M.A., Zimmerman, T.P., Reynolds-Vaughn, R., Wolberg G. (1987) Effects of adenosine on human neutrophil function and cyclic AMP content. In Topics and Perspectives in Adenosine Reseanch (E. Gerlach and B.F. Becker, eds), Springer-Verlag, Berlin, 286-298.

47. Weiss, S.J. (1989) Tissue destruction by neutrophils. N. Engh J. Med. 320, 365-376.

48. Keller, H., Niggli, V., Zimmermmann, A. (1991) Diversity in motile responses of human neutrophil granulocytes: functional meaning and cytoskeletal basis. In New Aspects of Human Polymonphonuclear Leukocytes (W.H. Hörl and P.J. Schollmeyer, eds), Plenum, New York, 23-37.

49. Bellavite, P., Chirumbolo, S., Lippi, G., Guzzo, P., Santonastaso, C. (1993) Homologous priming in chemotactic peptidestimulated neutrophils. Cell Biochem. Funct. 11, 93-100.

50. Davis, B.H., Walter, R.J., Pearson, C.B., Becker, E.L., Oliver, J.M. (1982) Membrane activity and topography of f-Met-Leu-Phe-treated polymorhonuclear leukocytes. Am. J. Pathol. 108, 206-216. 